\title{
Classification of Key Competencies for Construction Project Management : Literature Review and Content Analysis
}

\author{
Fatemeh Pariafsai ${ }^{1}$, Sadjad Pariafsai*2 \\ ${ }^{1}$ Department of Construction Science, Texas A\&M University, College Station, Texas, USA \\ ${ }^{2}$ Faculty of Engineering, Islamic Azad University, Tehran, Tehran, Iran \\ ${ }^{*}$ Corresponding Author Email: st_s_pariafsai@azad.ac.ir
}

\begin{abstract}
Article Info

Volume 8, Issue 3

Page Number: 211-234

Publication Issue :

May-June-2021

Article History

Accepted : 20 May 2021

Published: 30 May 2021

This paper investigates competency classifications in construction project management and the relevant fields as well as the tools and techniques applied for such classifications. A systematic review and a detailed content analysis of twentythree selected references from the American Society of Civil Engineers (ASCE) library published over the last three decades were conducted. The findings of the content analysis showed that for classifying competencies, the information gathering techniques "review" and "authors' perspective" were predominantly used in the selected sources, whereas the three techniques "factor analysis," "interview/ meeting," and "questionnaire/ survey" were seldom used. The content analysis of the selected references also indicated that competency, competency synonyms, competency subdivisions, or competency branches were classified into its components in many different ways. The most common classifications were identified, compared with each other, and the similarities and differences between them were addressed. The findings of this study are a step towards providing the literature with a comprehensive investigation of competency classifications and appropriate classification tools and techniques in the field of construction project management.
\end{abstract}

Keywords : Construction Project Management, Competency Classification Technique, Content Analysis

\section{INTRODUCTION}

The construction industry is considered the backbone of any economy (Pariafsai, 2016a, Omran and Suleiman, 2017). As a vibrant field that requires the adoption of new technology and construction methods (Farooqui et al., 2010, Pariafsai, 2016b,
Pariafsai, 2016e), it is one of the most dynamic project-based industrial sectors (Cheng et al., 2005, Love et al., 2002). The complex nature of construction projects typically involves crises, uncertainty, and suspense. Accordingly, construction projects are one of the most challenging areas to apply project management techniques (Bothma, 2013). Disparate 
groups from different organizations must collaboratively work for short periods to achieve project goals (Cheng et al., 2005, Pariafsai, 2013, Pariafsai, 2016c, Pariafsai, 2016d). It obliges project managers to flexibly respond to rapidly-changing project circumstances (Pariafsai, 2016f, Pariafsai, 2016g, Cheng et al., 2005).

Project management is, therefore, one of the most demanding roles within the modern construction industry (Cheng et al., 2005, Pariafsai, 2016h). The success of construction projects depends on several critical factors, including the competent project managers (Al Khalil, 2002, Kaklauskas et al., 2010, Kim and Huynh, 2008, Limsila and Ogunlana, 2008, Meade and Presley, 2002, Toor and Ogunlana, 2008). The competencies construction managers bring to a company largely determine the ultimate success of its projects (Farooqui and Ahmed, 2009). Accordingly, recruiting competent project managers is an essential challenge for organizations (Afshari and Nikolić, 2018).

Moreover, the already employed and the newly recruited construction project managers must timely adopt key competencies. Accordingly, a strategic plan is required to adequately update the competencies of construction project managers to enable them to manage the ever-increasing complexity of the construction industry. To reexamine how construction project managers should be educated and trained, the first step is to understand the nature of competencies they need to acquire to fill any competency gaps. As a step to developing a strategic plan for achieving such a goal, this study identifies common competency classifications in the field of CPM.

As shown in Figure 1, this study contributes to research and practice in two ways. First, by attempting to reach a standard for CPM competency classification, this study adds to the existing body of
CPM competency research. Second, it enables improving training programs and assessment criteria in the field of CPM. The results can also assist in the refinement of recruitment criteria and the long-term employability of construction project managers.

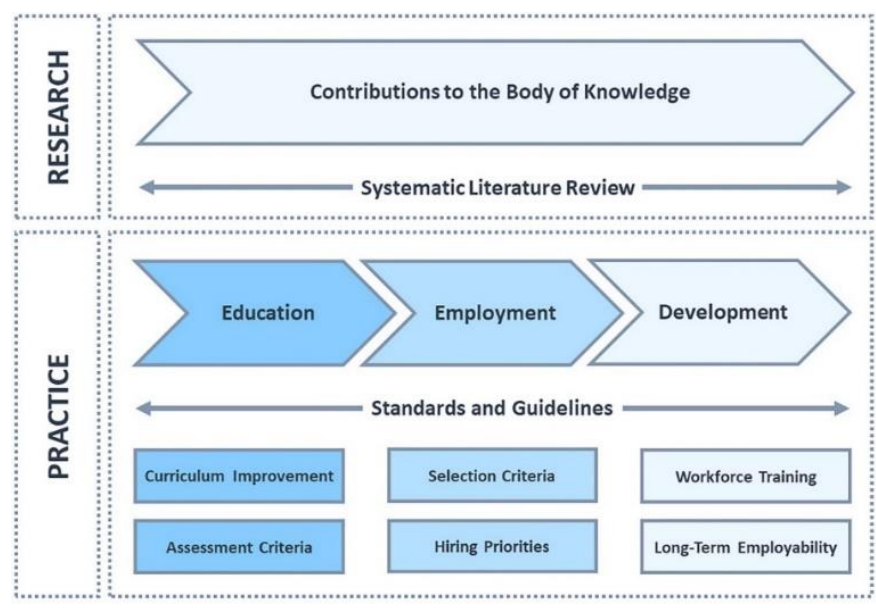

Figure 1. Contributions of the study (Pariafsai and Behzadan, 2021).

\section{BACKGROUND AND LITERATURE REVIEW}

Maximum performance occurs when workforce competencies are consistent with job requirements (Boyatzis, 1982). For this reason, organizations with more than 300 personnel usually use some form of competency-based human resource management (HRM) (Boyatzis and Boyatzis, 2008). Competencies were assumed to be more reliable predictors of managers' performance than the traditional psychological tests for measuring intelligence (McClelland, 1973). During the 1980s, the application of the competency approach expanded from selection procedures to other components of HRM, for instance, career development (van Klink and Boon, 2003).

The concept of competency is an ill-defined concept with no explicit content, thus allowing multiple interpretations (van Klink and Boon, 2003). The term "competent" comes from the Latin root "competence," which means "to be suitable" (GAPPS, 2007). Competency is defined as a capability or ability 
(Boyatzis and Boyatzis, 2008). It is a set of behavior organized around an underlying construct called "intent" (Boyatzis and Boyatzis, 2008). Behavior is another manifestation of intent, as appropriate in various situations (Boyatzis and Boyatzis, 2008). This construct of competency called for measurement methods that allowed for the assessment of behavior presence and intent inference (Boyatzis and Boyatzis, 2008). Competency is also defined in terms of unconscious personal characteristics and traits (Boyatzis, 1982, Turner and Crawford, 1992). Competences are defined as a set of related knowledge, skills, and personal characteristics related to job performance that can be improved (Parry, 1997). Competence is also defined as a combination of knowledge, experience, and personal attitudes. In this definition, knowledge and experience relate to function while attitude relates to behavior (Arendse, 2013).

As shown in Figure 2, the vagueness of the concept of competency is partly caused by the application of the concept in various countries, different settings, and for different purposes (van Klink and Boon, 2003). First, differences can be observed between nations (van Klink and Boon, 2003). In the United Kingdom, competence refers to the ability to meet the performance standards for functions and professions (van Klink and Boon, 2003). In the U.S., competency refers to the skills, knowledge, and characteristics of persons, which contribute to performance excellence (Spencer and Spencer, 2008). Competency is described as an iceberg with a person's knowledge and skills representing the visible tip of the iceberg, and enduring personal characteristics representing the hidden below the waterline (McClelland, 1973). According to this description, personal characteristics have a more substantive impact on individual job performance (Vazirani, 2010). Competence concerns work and its accomplishment, while competency is associated with people who do the work (Armstrong, 2006, Birkhead et al., 2000, Dainty et al., 2004,
Fletcher, 1997, Gareth, 1997, Sewchurran et al., 2010, Vazirani, 2010). In Germany, Kompetenz refers to a person's ability to perform various tasks within a certain profession (Bunk, 1994, Frei et al., 1984, Streumer and Bjorkquist, 1998).

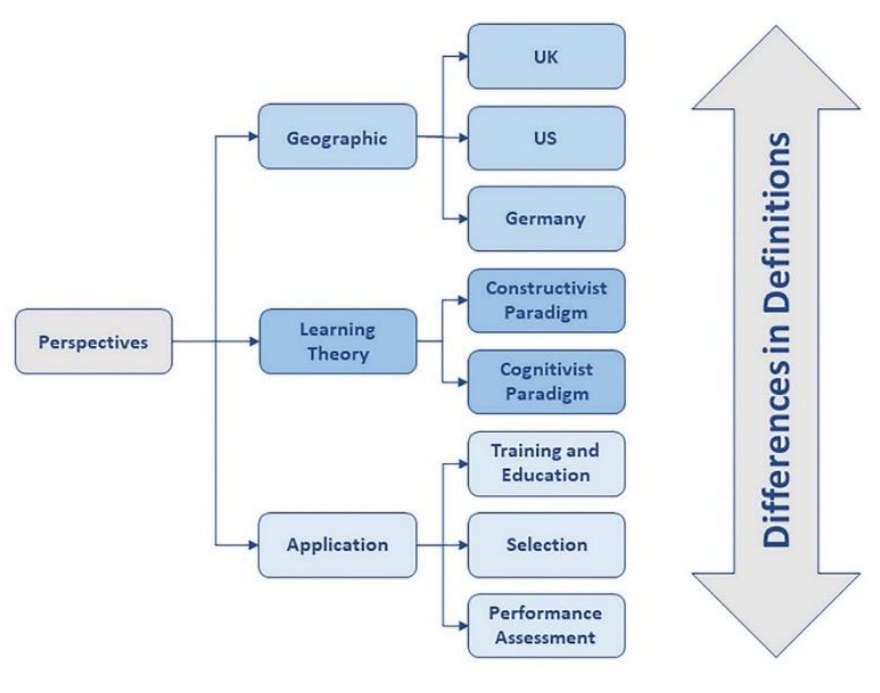

Figure 2. Different perspectives on the concept of competency (van Klink and Boon, 2003).

The second source of conceptual disagreement originates from learning theory (van Klink and Boon, 2003). The cognitivist learning paradigm links competencies with observable performance, while the constructivist learning paradigm emphasizes the employee's subjective perspective and preferences in the development and assessment of competencies (van Klink and Boon, 2003). Various applications in practice cause the third source of conceptual disagreement (van Klink and Boon, 2003). For education and training purposes, competencies can be regarded as a cluster of trainable skills, knowledge, and attitudes (van Klink and Boon, 2003). For selection procedures, competencies are usually defined as the individual's capabilities for future jobs, which may be trainable in part (van Klink and Boon, 2003). For performance assessment, the focus is on the output competencies deliver (van Klink and Boon, 2003). 
Despite the distinction in the meaning of competence and competency, the terms are still interchangeably used (Vazirani, 2010). For instance, project management competencies refer to a collection of knowledge, personal attitudes, skills, and relevant experience (Association, 2006). Project management competence is defined as what project managers bring to a project or project-related activity through their knowledge and understanding of project management, experience in the application of this knowledge and core attitude and personality traits that affect their behavior (Lindbergh, 2009). Competency is considered to comprise the following elements: (1) the actual performance of required skill, and (2) the personal attributes which underlie such performance (Birkhead et al., 2000). Alam et al. (2008) considered the following dimensions for competence: knowledge, skills, traits, motives, and self-concept. Knowledge and skills are easy to develop, whereas traits and motives are more difficult to develop (Arendse, 2013). Accordingly, selecting candidates that already possess these competences is more cost-effective (Arendse, 2013). Self-concept, comprising attitudes and values, lies in between and can change through personality development experiences (Arendse, 2013). Competencies are also classified into the following categories: input competencies, personal competencies, and output competencies. In this classification, input competencies refer to the knowledge and skills that a person brings to a job. Personal competencies are the core attributes underlying a person's capability to execute a job. Output competencies relate to the demonstrable performance that a person exhibits at the workplace (Crawford, 2005). The Project Management Institute (PMI) of the Project Manager Competency Development (PMCD) Framework believes in the following dimensions of competency: knowledge, personal competency, and performance (Arendse, 2013). Murray-Webster et al. (2011) mentioned knowledge, skills, experience, attitude, and personal characteristics as five core elements of a competency.
Ballesteros Sánchez et al. (2017) have shown that there is a broad consensus about two different types of project management competences: (1) knowledge and technical competences, called hard skills, and (2) interpersonal skills and behavioral competences, called soft skills. Hard skills, e.g. technical skills and field experience, (Rezk et al., 2018), are tangible and measurable, whereas, soft skills, e.g. leadership and management skills (Rezk et al., 2018), are intangible and immeasurable (Ogunsanmi, 2016). Project managers' soft skills are more critical predictors of their performance (Ahadzie et al., 2008b).

Based on the literature, project management competencies are generic (Birkhead et al., 2000). The characteristics of a successful project manager are consistent, regardless of industry sector, corporate culture, or other factors (Gould and Freeman, 2004). The technical skills that a construction project manager requires are specific to the construction industry, whereas general management competencies can be easily transferred between various disciplines of project management (Edum-Fotwe and Mccaffer, 2000). Both job-task and behavioral competencies contribute to project managers' superior performance within the construction industry. Job-task competencies are highly specific to the industry, while behavioral competencies are mostly generic (Omran and Akram, 2017).

Most previous studies have tried to identify the competencies required for construction project managers. The desired competencies for CPM and related fields have also been classified using different approaches in the past. However, no study has conducted a comprehensive content analysis to identify a standard for competency classification in the field of CPM. As a step to bridging this gap in the literature, this study conducts a content analysis of competency classification in the field of CPM and relevant areas. 


\section{METHODS AND MATERIAL}

As shown in Figure 3, a three-stage process was adopted to achieve the research objectives. These stages are described in the following Subsections.

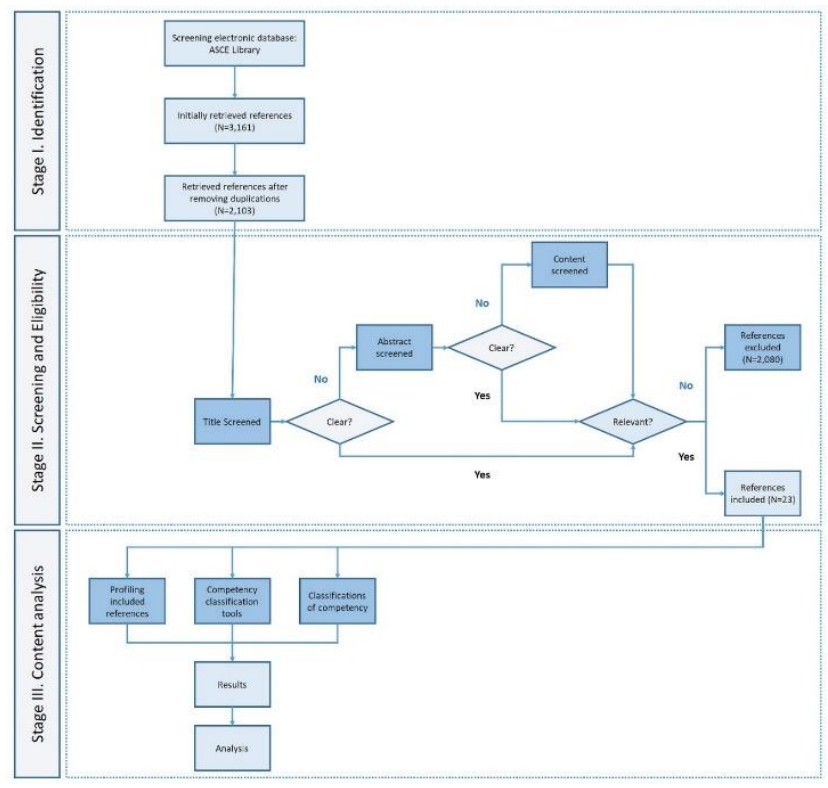

Figure 3. Stages of research methodology.

\section{A. Identification}

In Stage I, potentially relevant references were searched using the search engine of the American Society of Civil Engineers (ASCE) Library. This repository was selected since ASCE has an important impact on and holds a prominent position in the construction engineering and management research community. Additionally, the results extracted from the ASCE references help understand the content, pertinent to this research, beyond the immediate domain of civil engineering. In the ASCE Library, "advanced search" was used to find applicable references through specific search terms, topics, and publication dates. For topics, the term "construction" was used. The option "title" was checked for where search terms would be searched. The search terms used included competencies, competence, skill, capability, knowledge, project manager, project management, construction management, and engineering management. These search terms were selected from previously published studies that conducted either research or review on competencyrelated topics, and they were based on an initial examination of common keywords used in competency-related studies published in the CPM domain such as "Key Skills for Graduating Construction Management Students - A Comparative Study of Industry and Academic Perspectives" (Farooqui and Ahmed, 2009), "Desirable Attributes and Skills for Graduating Construction Management Students" (Ahmed and Saqib, 2010), "Developing Project Management Competency: Perspectives from the Construction Industry" (Edum-Fotwe and Mccaffer, 2000), "Management Skills and Knowledge: A Case Example from the Construction Industry" (Young, 1989), "Project Management Training: An Integrative Approach for Strengthening the Soft Skills of Engineering Students" (BallesterosSánchez et al., 2017), and "Evaluation of Management Challenges Facing Construction Practice in Nigeria" (Okoye et al., 2015). For more representative results, the search was restricted to references inclusively published from 1988 to 2019. Whenever more than one chapter of a book was found, instead of counting all the chapters, the book was counted as one reference. In such cases, the book title might exclude all the search terms used. If the same reference was found under different search terms, it was counted under each specific search term. This process resulted in 3,161 references that were initially retrieved from the ASCE Library. Removal of duplications yielded 2,102 references (Pariafsai, 2020).

\section{B. Screening and Eligibility}

In Stage II, the titles, abstracts, and contents of the references were further examined using the process laid out in Fig. 3 to determine the appropriateness of content for inclusion in this review study. Whenever the name of a reference source, not the title of the reference, included the search term, the reference was excluded from further examination. Search results such as announcement, call for papers, closure 
to a reference, discussion of a reference, erratum for a reference, best feature article award, updates to a journal's editorial board, and so forth were also excluded from further checking. When the title of a reference only included part of a search term, e.g., "engine" or "engineered" instead of "engineering management," the reference was considered irrelevant. If a title included a search term combined with another word that conveyed a different meaning, e.g., "knowledge management" instead of "knowledge," the reference was considered irrelevant. If a title included both words of a two-word search term but the words were apart in the title, thus conveying a different meaning, the reference was considered irrelevant. For instance, the title "Risk Management and the Effects on Project Success" includes both words of the search term "project management," but the reference is extraneous to the topic of this study. If a title included a search term but the title's content was inapposite, e.g., "Action Research as a Proactive Method for Construction Engineering and Management," the reference was considered irrelevant.

The following inclusion criteria were used to select the references: (1) In this study, competency classification refers to either an implementation of or a reference to a classification of competency, competency synonyms, competency subdivisions, or one of the competency branches (for instance, professional competency). Competency synonyms stand for competence, requirement, and outcome. Competency subdivisions refer to skill, capability, and knowledge; (2) The reference could be either directly or indirectly relevant to the topic of this study. Not only the references containing information on competency classification in the area of CPM but also those concerning competency classification in the areas "general," "leadership," "management," "project management," "engineering," "leadership in engineering," "engineering management," "construction," "construction professionals," "construction management," and "construction project management" were selected; and (3) As part of its content, the reference might classify or refer to the classification of competency, competency synonyms, competency subdivisions, or one of the competency branches. Following these three inclusion criteria, 23 of the 2,102 initially found references (Pariafsai, 2020) were selected for content analysis.

\section{Content Analysis}

In Stage III, once the references were identified, a detailed content analysis was carried out to (1) profile the selected references based on the search term(s), publication year, geographical region of the resource parts used for content analysis, resource type, and subject area; (2) examine common competency classification tools and techniques; and (3) systematically identify and categorize common competency classifications from the selected references. Content analysis is a research technique for determining major facets of and valid inferences from written, verbal, or visual communication messages, either qualitatively or quantitatively, depending on the nature of the project and the issues to be addressed in the research (Chan et al., 2009, Krippendorff, 2018). Content analysis is a powerful technique for collecting and organizing information and for examining trends and patterns in documents (Krippendorff, 2018). The qualitative content analysis focuses on grouping data into categories. In contrast, quantitative content analysis determines the numerical values of categorized data (i.e., frequencies, ratings, and rankings) by simply counting the number of times a topic is mentioned (Chan et al., 2009). In this study, a combination of both qualitative and quantitative content analysis was adopted.

\section{RESULTS AND DISCUSSION}

The complete list of selected references used for the content analysis is provided in Table SI (see Supplemental Data). The percentage values indicated 
in the discussion, Figures, and Tables were determined based on the number of references over the total number of references considered in the content analysis (i.e., 23 references). Table 1 shows the number of references initially retrieved and finally selected (before the removal of duplicate references) based on publication date and specific search terms.

Table 1. Number of references initially retrieved and finally selected (before the removal of duplicate references) based on publication date and specific search terms (R: retrieved; S: selected

\begin{tabular}{|c|c|c|c|c|c|c|c|c|c|c|c|c|c|c|c|c|c|c|}
\hline & \multicolumn{18}{|c|}{ Search term } \\
\hline $\begin{array}{l}\text { P } \\
\text { u } \\
\text { bl } \\
\text { ic } \\
\text { at }\end{array}$ & \multicolumn{2}{|c|}{$\begin{array}{c}\text { Proje } \\
\text { ct } \\
\text { man } \\
\text { ager }\end{array}$} & \multicolumn{2}{|c|}{$\begin{array}{c}\text { Proje } \\
\text { ct } \\
\text { mana } \\
\text { geme } \\
\text { nt }\end{array}$} & \multicolumn{2}{|c|}{$\begin{array}{l}\text { Constru } \\
\text { ction ma } \\
\text { nageme } \\
\text { nt }\end{array}$} & \multicolumn{2}{|c|}{$\begin{array}{c}\text { Enginee } \\
\text { ring ma } \\
\text { nageme } \\
\text { nt }\end{array}$} & \multicolumn{2}{|c|}{$\begin{array}{c}\text { Comp } \\
\text { etenci } \\
\text { es }\end{array}$} & \multicolumn{2}{|c|}{$\begin{array}{c}\text { Comp } \\
\text { etenc } \\
\mathrm{e}\end{array}$} & \multicolumn{2}{|c|}{$\begin{array}{c}\text { Capa } \\
\text { bility }\end{array}$} & \multicolumn{2}{|c|}{ Skill } & \multicolumn{2}{|c|}{$\begin{array}{c}\text { Kno } \\
\text { wled } \\
\text { ge }\end{array}$} \\
\hline $\begin{array}{l}\mathrm{n} \\
\mathrm{da} \\
\text { te }\end{array}$ & $\mathrm{R}$ & S & $\mathrm{R}$ & S & $\mathrm{R}$ & S & $\mathrm{R}$ & S & $\mathrm{R}$ & S & $\mathrm{R}$ & S & $\mathrm{R}$ & S & $\mathrm{R}$ & S & $\mathrm{R}$ & S \\
\hline $\begin{array}{l}19 \\
88 \\
- \\
19 \\
89\end{array}$ & 4 & 0 & 4 & 0 & 11 & 0 & 7 & 1 & 0 & 0 & 0 & 0 & 0 & 0 & 0 & 0 & $\begin{array}{l}1 \\
1\end{array}$ & 0 \\
\hline $\begin{array}{l}19 \\
90 \\
- \\
19 \\
91\end{array}$ & 5 & 0 & 5 & 0 & 11 & 0 & 7 & 0 & 0 & 0 & 0 & 0 & 0 & 0 & 0 & 0 & $\begin{array}{l}1 \\
2\end{array}$ & 0 \\
\hline $\begin{array}{l}19 \\
92 \\
- \\
19 \\
93\end{array}$ & 8 & 1 & 8 & 1 & 10 & 0 & 18 & 0 & 1 & 0 & 1 & 0 & 1 & 0 & 1 & 1 & $\begin{array}{l}1 \\
0\end{array}$ & 0 \\
\hline $\begin{array}{l}19 \\
94 \\
- \\
19 \\
95\end{array}$ & $\begin{array}{l}1 \\
2\end{array}$ & 0 & $\begin{array}{l}1 \\
2\end{array}$ & 0 & 7 & 0 & 7 & 0 & 0 & 0 & 0 & 0 & 0 & 0 & 0 & 0 & 6 & 0 \\
\hline $\begin{array}{l}19 \\
96 \\
- \\
19 \\
97\end{array}$ & $\begin{array}{l}1 \\
5\end{array}$ & 0 & $\begin{array}{l}1 \\
4\end{array}$ & 0 & 17 & 0 & 17 & 0 & 0 & 0 & 0 & 0 & 1 & 0 & $\begin{array}{l}1 \\
2\end{array}$ & 0 & 5 & 0 \\
\hline $\begin{array}{l}19 \\
98 \\
- \\
19 \\
99\end{array}$ & $\begin{array}{l}2 \\
3\end{array}$ & 0 & $\begin{array}{l}2 \\
3\end{array}$ & 0 & 17 & 0 & 16 & 0 & 0 & 0 & 0 & 0 & 3 & 0 & $\begin{array}{l}1 \\
0\end{array}$ & 0 & 1 & 0 \\
\hline $\begin{array}{l}20 \\
00 \\
- \\
20 \\
01\end{array}$ & $\begin{array}{l}3 \\
3\end{array}$ & 0 & $\begin{array}{l}3 \\
3\end{array}$ & 0 & 32 & 0 & 38 & 0 & 3 & 0 & 3 & 0 & 6 & 0 & 3 & 0 & $\begin{array}{l}2 \\
0\end{array}$ & 0 \\
\hline $\begin{array}{l}20 \\
02 \\
- \\
20 \\
03\end{array}$ & $\begin{array}{l}3 \\
8\end{array}$ & 0 & $\begin{array}{l}3 \\
9\end{array}$ & 0 & 52 & 0 & 30 & 0 & 1 & 0 & 1 & 0 & 9 & 0 & 4 & 1 & $\begin{array}{l}2 \\
7\end{array}$ & 0 \\
\hline
\end{tabular}

\begin{tabular}{|c|c|c|c|c|c|c|c|c|c|c|c|c|c|c|c|c|c|c|}
\hline $\begin{array}{l}20 \\
04 \\
- \\
20 \\
05 \\
\end{array}$ & $\begin{array}{l}4 \\
4\end{array}$ & 0 & $\begin{array}{l}4 \\
4\end{array}$ & 0 & 69 & 0 & 69 & 0 & 2 & 0 & 2 & 0 & 6 & 0 & 3 & 0 & $\begin{array}{l}2 \\
3\end{array}$ & 0 \\
\hline $\begin{array}{l}20 \\
06 \\
- \\
20 \\
07\end{array}$ & $\begin{array}{l}1 \\
8\end{array}$ & 0 & $\begin{array}{l}3 \\
6\end{array}$ & 0 & 44 & 0 & 62 & 0 & 1 & 0 & 6 & 0 & $\begin{array}{l}1 \\
3\end{array}$ & 0 & 5 & 1 & $\begin{array}{l}3 \\
0\end{array}$ & 0 \\
\hline $\begin{array}{l}20 \\
08 \\
- \\
20 \\
09\end{array}$ & $\begin{array}{l}6 \\
9\end{array}$ & 1 & $\begin{array}{l}5 \\
1\end{array}$ & 1 & 51 & 2 & 53 & 0 & 1 & 1 & 1 & 1 & $\begin{array}{l}2 \\
2\end{array}$ & 0 & 7 & 0 & $\begin{array}{l}3 \\
3\end{array}$ & 0 \\
\hline $\begin{array}{l}20 \\
10 \\
- \\
20 \\
11\end{array}$ & $\begin{array}{l}4 \\
9\end{array}$ & 0 & $\begin{array}{l}4 \\
7\end{array}$ & 0 & 77 & 0 & 39 & 0 & 6 & 2 & 8 & 2 & $\begin{array}{l}1 \\
7\end{array}$ & 0 & 7 & 0 & $\begin{array}{l}2 \\
9\end{array}$ & 0 \\
\hline $\begin{array}{l}20 \\
12 \\
- \\
20 \\
13\end{array}$ & $\begin{array}{l}6 \\
1\end{array}$ & 0 & $\begin{array}{l}5 \\
9\end{array}$ & 0 & $\begin{array}{c}11 \\
7\end{array}$ & 0 & 48 & 0 & 5 & 2 & 6 & 3 & $\begin{array}{l}1 \\
7\end{array}$ & 0 & 6 & 1 & $\begin{array}{l}4 \\
0\end{array}$ & 1 \\
\hline $\begin{array}{l}20 \\
14 \\
- \\
20 \\
15\end{array}$ & $\begin{array}{l}6 \\
5\end{array}$ & 0 & $\begin{array}{l}6 \\
5\end{array}$ & 0 & $\begin{array}{c}10 \\
4\end{array}$ & 0 & 68 & 0 & 5 & 1 & 9 & 1 & $\begin{array}{l}1 \\
3\end{array}$ & 0 & 5 & 1 & $\begin{array}{l}5 \\
4\end{array}$ & 0 \\
\hline $\begin{array}{l}20 \\
16 \\
- \\
20 \\
17\end{array}$ & $\begin{array}{l}7 \\
5\end{array}$ & 4 & $\begin{array}{l}7 \\
5\end{array}$ & 4 & $\begin{array}{c}11 \\
6\end{array}$ & 4 & 46 & 1 & 5 & 3 & 6 & 3 & $\begin{array}{l}1 \\
4\end{array}$ & 0 & 9 & 1 & $\begin{array}{l}3 \\
4\end{array}$ & 2 \\
\hline $\begin{array}{l}20 \\
18 \\
- \\
20 \\
19\end{array}$ & $\begin{array}{l}5 \\
0\end{array}$ & 1 & $\begin{array}{l}4 \\
8\end{array}$ & 1 & 79 & 1 & 26 & 0 & 7 & 1 & $\begin{array}{l}1 \\
2\end{array}$ & 1 & $\begin{array}{l}1 \\
5\end{array}$ & 0 & 5 & 0 & $\begin{array}{l}2 \\
3\end{array}$ & 0 \\
\hline $\begin{array}{l}\mathrm{T} \\
\text { ot } \\
\text { al }\end{array}$ & $\begin{array}{l}5 \\
6 \\
9\end{array}$ & 7 & $\begin{array}{l}5 \\
6 \\
3\end{array}$ & 7 & $\begin{array}{c}81 \\
4\end{array}$ & 7 & $\begin{array}{c}55 \\
1\end{array}$ & 2 & $\begin{array}{l}3 \\
7\end{array}$ & $\begin{array}{l}1 \\
0\end{array}$ & $\begin{array}{l}5 \\
5\end{array}$ & $\begin{array}{l}1 \\
1\end{array}$ & $\begin{array}{l}1 \\
3 \\
7\end{array}$ & 0 & $\begin{array}{l}7 \\
7\end{array}$ & 6 & $\begin{array}{l}3 \\
5 \\
8\end{array}$ & 3 \\
\hline
\end{tabular}

\section{Profile of the Selected References}

Selected references for content analysis were profiled based on search terms, publication year, geographical region of extracted parts of the selected references, resource type, and subject area. Table 2 shows the percentage of the selected references found under each search term. The first rank belonged to the search term competence (43.5\%), followed by competencies (39.1\%). Under each of the search terms project manager, project management, construction management, and skill, $26.1 \%$ of the selected references were initially retrieved from the database. The next common search term was knowledge (13.5\%). The least common search term was engineering management $(8.7 \%)$. None of the 
references found under the search term capability was selected for the content analysis.

Table 2. Search terms used to find selected references

\begin{tabular}{|l|c|c|c|}
\hline Search term & $\begin{array}{c}\text { Number } \\
\text { of } \\
\text { referenc } \\
\text { es }\end{array}$ & $\begin{array}{c}\text { Percenta } \\
\text { ge of } \\
\text { reference } \\
\text { s }\end{array}$ & $\begin{array}{c}\text { Ran } \\
\mathbf{k}\end{array}$ \\
\hline Competence & 10 & 43.5 & 1 \\
\hline Competencies & 9 & 39.1 & 2 \\
\hline Project manager & 6 & 26.1 & 3 \\
\hline Project management & 6 & 26.1 & 3 \\
\hline $\begin{array}{l}\text { Construction managem } \\
\text { ent }\end{array}$ & 6 & 26.1 & 3 \\
\hline Skill & 6 & 26.1 & 3 \\
\hline Knowledge & 3 & 13.5 & 4 \\
\hline $\begin{array}{l}\text { Engineering manageme } \\
\text { nt }\end{array}$ & 2 & 8.7 & 5 \\
\hline Capability & 0 & 0 & 6 \\
\hline
\end{tabular}

As shown in Table 3, selected references were published between 1988 and 2019. However, the number of selected references published from 2010 to 2019 (73.9\%) was considerably greater than any other publication period, implying the growth of demand for research on competency classification over the world in the last decade. Moreover, most extracted parts of the selected references belonged to the geographical region "general" (73.9\%), implying that either the geographical region of these parts was not stated in the selected references, the parts were related to more than one geographical location, or the classification method applied in those parts was "literature review." The second most common region was North and Central America (17.4\%). The least common regions were Asia (8.7\%). In addition, none of the extracted parts was related to Africa, Australia, Europe, or South America (Table 3). The geographical distribution of the extracted parts reflects the growing demand for research on competency classification in those geographical regions.
Table 3. Profile of the selected references

\begin{tabular}{|c|c|c|c|c|}
\hline Feature & \multicolumn{2}{|c|}{ Category } & $\begin{array}{l}\text { Number } \\
\text { of } \\
\text { referenc } \\
\text { es }\end{array}$ & $\begin{array}{c}\text { Percenta } \\
\text { ge of } \\
\text { reference } \\
\text { s }\end{array}$ \\
\hline \multirow{5}{*}{$\begin{array}{l}\text { Publicatio } \\
\text { n year }\end{array}$} & $\begin{array}{l}\text { Period } \\
\text { I }\end{array}$ & $\begin{array}{l}1988- \\
1989\end{array}$ & 1 & 4.35 \\
\hline & $\begin{array}{l}\text { Period } \\
\text { II }\end{array}$ & $\begin{array}{l}1990- \\
1999\end{array}$ & 1 & 4.35 \\
\hline & $\begin{array}{l}\text { Period } \\
\text { III }\end{array}$ & $\begin{array}{l}2000- \\
2009\end{array}$ & 4 & 17.4 \\
\hline & $\begin{array}{l}\text { Period } \\
\text { IV }\end{array}$ & $\begin{array}{l}2010- \\
2019\end{array}$ & 17 & 73.9 \\
\hline & \multicolumn{2}{|l|}{ Total } & 23 & 100 \\
\hline \multirow{8}{*}{$\begin{array}{l}\text { Geographi } \\
\text { cal Region }\end{array}$} & \multirow{6}{*}{$\begin{array}{l}\text { Catego } \\
\text { ry I }\end{array}$} & Africa & 0 & 0 \\
\hline & & Asia & 2 & 8.7 \\
\hline & & $\begin{array}{l}\text { Austral } \\
\text { ia }\end{array}$ & 0 & 0 \\
\hline & & Europe & 0 & 0 \\
\hline & & $\begin{array}{l}\text { North } \\
\text { and } \\
\text { Central } \\
\text { Americ } \\
\text { a }\end{array}$ & 4 & 17.4 \\
\hline & & $\begin{array}{l}\text { South } \\
\text { Americ } \\
\text { a }\end{array}$ & 0 & 0 \\
\hline & $\begin{array}{l}\text { Catego } \\
\text { ry II }\end{array}$ & $\begin{array}{l}\text { Genera } \\
1\end{array}$ & 17 & 73.9 \\
\hline & \multicolumn{2}{|l|}{ Total } & 23 & 100 \\
\hline
\end{tabular}

Figure 4 depicts the number of selected references published in each resource type. Close to $74 \%$ of the selected references were published in the following journals: Journal of Construction Engineering and Management (21.7\%), Journal of Management in Engineering (21.7\%), Journal of Professional Issues in Engineering Education and Practice (17.4\%), Leadership and Management in Engineering (8.7\%), and Journal of Computing in Civil Engineering (4.4\%). 
Moreover, one of the selected references was a book chapter (4.4\%). The remaining $21.7 \%$ of selected references were published in ASCE conference proceedings.

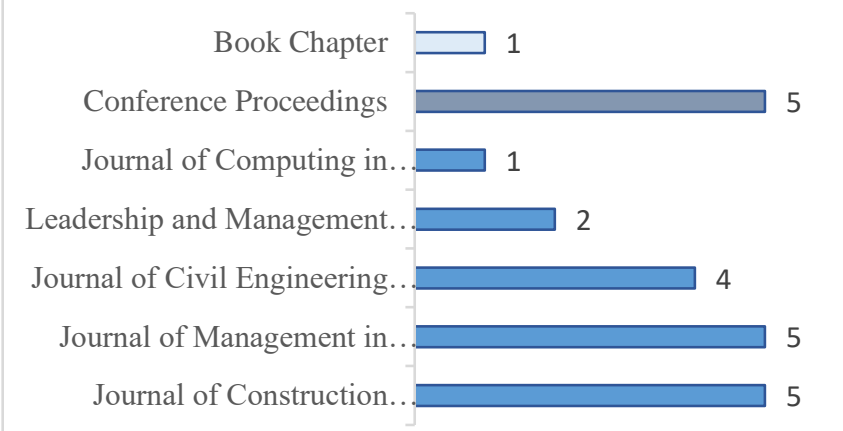

Figure 4. The number of selected references by resource type.

Selected references were also profiled based on competency classification subject areas (Table 4). To avoid redundancy, relevant subject areas were grouped into four main categories. Most of the extracted parts of the selected references (65.2\%) belonged to category IV, including subject areas "construction," "construction professional," "construction management," and "construction project management." Category II, including subject areas "leadership," "management," and "project management," was the second common category (43.5\%). The third common subject areas, including "engineering," "leadership in engineering," and "engineering management," belonged to category III (17.4\%). The least common category was category I related to the subject area "general" with only two selected references (8.7\%). Accordingly, most of the classifications were related to either "construction" or "management" as two main subject areas.

Table 4. Competency classification subject area

\begin{tabular}{|l|l|c|c|}
\hline $\begin{array}{l}\text { Catego } \\
\text { ry }\end{array}$ & Subject area & $\begin{array}{c}\text { Number } \\
\text { of } \\
\text { referenc } \\
\text { es }\end{array}$ & $\begin{array}{c}\text { Percenta } \\
\text { ge of } \\
\text { referenc } \\
\text { es }\end{array}$ \\
\hline I & General & 2 & 8.7 \\
\hline
\end{tabular}

\begin{tabular}{|l|l|c|c|}
\hline \multirow{4}{*}{ II } & Leadership & 1 & \multirow{4}{*}{43.5} \\
\cline { 2 - 3 } & Management & 3 & \\
\cline { 2 - 3 } & Project management & 6 & \\
\hline \multirow{5}{*}{ III } & Engineering & 2 & \multirow{2}{*}{17.4} \\
\cline { 2 - 3 } & $\begin{array}{l}\text { Leadership in } \\
\text { Engineering }\end{array}$ & 1 & \\
\cline { 2 - 3 } & $\begin{array}{l}\text { Engineering manage } \\
\text { ment }\end{array}$ & 1 & \multirow{2}{*}{65.2} \\
\hline \multirow{5}{*}{ IV } & $\begin{array}{l}\text { Construction } \\
\text { Construction } \\
\text { professional }\end{array}$ & 8 & \\
\cline { 2 - 3 } & $\begin{array}{l}\text { Construction } \\
\text { management }\end{array}$ & 2 & \\
\cline { 2 - 3 } & $\begin{array}{l}\text { Construction project } \\
\text { management }\end{array}$ & 4 & \\
\hline
\end{tabular}

\section{E. Competency Classification Tools and Techniques Used in the Selected References}

Authors of the 23 selected references either applied or referred to at least one competency classification tool or technique. In this article, the applied tools and techniques were grouped into the following categories: authors' perspective, factor analysis, interview/ meeting, questionnaire/ survey, and review. "Authors' perspective" refers to classification based on the authors' perspective, opinion, discussion, experience, tentative categorization, and what they proposed or mentioned. "Interview/ meeting" stands for interviews, meetings, telephone conferences, and e-mail discussions. "Questionnaire/ Survey" refers to questionnaires, surveys, and the Delphi method. "Review" is used for classification based on a competency dictionary, literature review, review of available certificates, and the results of a previous presentation/ workshop/ research. Table 5 presents the frequency of tools/ techniques used for competency classification in selected references, regardless of being used alone or in combination with other tools/ techniques. 
Table 5. Competency classification tools and techniques

\begin{tabular}{|l|c|c|c|}
\hline Tools and techniques & $\begin{array}{c}\text { Number } \\
\text { of } \\
\text { reference } \\
\mathbf{s}\end{array}$ & $\begin{array}{c}\text { Percentag } \\
\text { e of } \\
\text { references }\end{array}$ & $\begin{array}{c}\text { Ran } \\
\mathbf{k}\end{array}$ \\
\hline Review & 15 & 50 & 1 \\
\hline Authors' perspective & 9 & 30 & 2 \\
\hline Factor analysis & 2 & 6.7 & 3 \\
\hline Interview/Meeting & 2 & 6.7 & 3 \\
\hline $\begin{array}{l}\text { Questionnaire/Surve } \\
\text { y }\end{array}$ & 2 & 6.7 & 3 \\
\hline Total & 30 & 100 & - \\
\hline
\end{tabular}

The most common competency classification technique was "review" (50\%). "Authors' perspective" was the second most favored competency classification technique (30\%). Each of the other techniques/ tools, including "factor analysis," "interview/ meeting," and "questionnaire/ survey," was rarely used (6.7\%). The existence of various competency classification tools and techniques in the literature makes it challenging to select a single tool and technique for CPM competency classification.

\section{F. Competency Classifications in the Selected References}

Further analysis of the selected references indicated that competency, competency synonyms, competency subdivisions, or one of the competency branches (for instance, professional competency) were classified in many different ways. In this article, competency synonyms stand for competence, requirement, and outcome. Competency subdivisions refer to skill, capability, and knowledge. In the subject area "general," competency was classified into the following three categories: knowledge, skills, and habits/ behavior (Table 6). Knowledge is referred as information an expert (e.g. an estimator) has attained related to his/ her expertise (e.g. estimating) (Alroomi et al., 2012). Skill is the ability to perform a certain professional task (e.g. a certain estimating task) (Alroomi et al., 2012). Habit is defined as something that a person does regularly or usually, often without thinking about it because he/ she has done it so many times before (Longman, 2020b). Behavior is defined as a response of an individual or group to an action, environment, person, or stimulus (BusinessDictionary, 2018).

Table 6. Classification in category I

\begin{tabular}{|c|c|c|c|}
\hline $\begin{array}{l}\text { Subject } \\
\text { area }\end{array}$ & $\begin{array}{l}\text { Main } \\
\text { element }\end{array}$ & Components & Frequency \\
\hline \multirow{6}{*}{ General } & \multirow{3}{*}{ Competency } & Knowledge & \multirow{3}{*}{1} \\
\hline & & Skills & \\
\hline & & Habits & \\
\hline & \multirow{3}{*}{ Competency } & Knowledge & \multirow{3}{*}{1} \\
\hline & & Skills & \\
\hline & & Behavior & \\
\hline
\end{tabular}

Table 7 presents the identified components in category II, that includes the subject areas "leadership," "management," and "project management." In the subject area "leadership," requirements, as a synonym of competencies, were classified into individual characteristics and learnable skills. Individual characteristics essential for leaders include passion, persistence, patience, and a sense of self (Prieto, 2013). Learnable leadership skills, on the other hand, include communication, continuous learning, empowerment, and sense of team, doing, and motivation (Prieto, 2013). This classification is comparable to the competency classification in category I. Individual characteristics can be considered similar to habits/ behavior. Moreover, knowledge and skills can be developed easily (Arendse, 2013). Accordingly, they are comparable to learnable skills. In the subject area "management," competency was categorized into: (1) generic and specific competencies; and (2) managing change (including managing change initiative, risk-taking, innovation, and flexibility and adaptability) (Arditi 
and Balci, 2009), planning and organizing (including planning and organizing analytical thinking, decision making, planning, and quality focus) (Arditi and Balci, 2009), interpersonal skills (including oral communication, sensitivity, relationships, and teamwork) (Arditi and Balci, 2009), result orientation (including achievement, customer focus, business awareness, and learning orientation) (Arditi and Balci, 2009), and leadership (including authority and presence, motivating others, developing people, and resilience) (Arditi and Balci, 2009). Generic competencies are the behaviors that high performers may display, though in different proportions according to level, function, or context (Kwok, 2004). Specific competencies, on the other hand, are those required for specific project-based sectors and/or industries (Ahadzie et al., 2008a). In this subject area, skills were classified into technical skills, human skills, and conceptual skills. A technical skill is defined as an understanding of, and proficiency in, a special kind of activity particularly involving methods, processes, procedures, or techniques (Katz, 2009). A human skill, on the other hand, is an executive ability of a leader to work effectively as a group member and to build cooperative effort within the team he leads (Katz, 2009). A conceptual skill can be described as the ability to coordinate and integrate all the activities and interests of the organization towards a common objective (Katz, 2009). In the third subject area in category II, i.e. project management, competency and skill were classified in two and five different ways, respectively. "Skills and capabilities" and "knowledge areas" were also grouped into their components. In the same way as competency classification in category I, one reference classified competency into knowledge, skills, and behavior. Another reference categorized competency into knowledge, performance, and personal competency. A project manager's knowledge competence is what the project manager knows about the application of processes, tools, and techniques for project activities (PMI, 2007). Performance competence, on the other hand, is what the project manager can do or accomplish by applying their project management knowledge (PMI, 2007). Personal competencies are those behaviors, attitudes, and core personality characteristics that contribute to a person's ability to manage projects (PMI, 2007). The latter classification is comparable to the former. While the category "knowledge" is the same in both classifications, the components "skills" and "performance" can be considered similar because skills have also been treated as performances (Engeström, 1994). The categories "behavior" and "personal competencies" can be considered the same. Furthermore, two references classified skills into the following components: technical skills, human skills, conceptual skills, and negotiating skills. Negotiators seek to increase common interest and expand cooperation to broaden the agreement to cover an item under dispute (Zartman, 1976). This skill classification is similar to the skill classification in the subject area "management." The only difference relates to adding the component "negotiating skills" in the former classification. Although all five skill classifications were different, some components were the same among them. For instance, all five classifications included the component "technical skills," and three of them considered "Leadership skills" as one of the components. Leadership skills are the abilities to lead the team and integrate individual demands, requirements, and limitations into decisions that will affect overall project performance (Kerzner, 2017). "Leadership skills" was also a component in one of two competency classifications in the subject area "management." The components "administrative skills" and "organizational skills" were also appeared in two skill classifications. Administrative skills involve planning, staffing, budgeting, scheduling, and other control techniques (Kerzner, 2017). Organizational skills, on the other hand, are about understanding how the organization works and how to work with the organization (Kerzner, 2017). Moreover, "planning and organizing" was appeared as a 
component in one of the competency classifications in the subject area "management." It can be considered similar to the component "organizational skills" that appeared two times as a skill component in the subject area "project management." In addition, "interpersonal skills," which was a competency component in the area "management," was also appeared as a skill component in the area "project management." Table 7 represents all other components in each skill classification. Furthermore, "skills and capabilities" were classified into hard and soft skills. Knowledge areas were also divided into "generic" and "practice-specific," which is the same as a competency classification in the subject area "management." Generic project management knowledge should be offered in educational institutions, whereas more practice-specific knowledge in an industry-related setting (Córdoba and Piki, 2012).

Table 7. Classification in category II

\begin{tabular}{|c|c|c|c|}
\hline $\begin{array}{l}\text { Subject } \\
\text { area }\end{array}$ & $\begin{array}{l}\text { Main } \\
\text { element }\end{array}$ & Components & $\begin{array}{c}\text { Frequen } \\
\text { cy }\end{array}$ \\
\hline \multirow[t]{2}{*}{ Leadership } & \multirow{2}{*}{$\begin{array}{l}\text { Requireme } \\
\text { nts }\end{array}$} & $\begin{array}{l}\text { Individual } \\
\text { characteristic } \\
\mathrm{s}\end{array}$ & \multirow[t]{2}{*}{1} \\
\hline & & $\begin{array}{l}\text { Learnable } \\
\text { skills }\end{array}$ & \\
\hline \multirow{8}{*}{$\begin{array}{l}\text { Manageme } \\
\text { nt }\end{array}$} & \multirow{2}{*}{$\begin{array}{l}\text { Competenc } \\
\mathrm{y}\end{array}$} & Generic & \multirow{2}{*}{1} \\
\hline & & Specific & \\
\hline & \multirow{5}{*}{$\begin{array}{l}\text { Competenc } \\
\mathrm{y}\end{array}$} & $\begin{array}{l}\text { Managing } \\
\text { change }\end{array}$ & \multirow{5}{*}{1} \\
\hline & & $\begin{array}{l}\text { Planning and } \\
\text { organizing }\end{array}$ & \\
\hline & & $\begin{array}{l}\text { Interpersonal } \\
\text { skills }\end{array}$ & \\
\hline & & $\begin{array}{l}\text { Result } \\
\text { orientation }\end{array}$ & \\
\hline & & Leadership & \\
\hline & Skills & $\begin{array}{l}\text { Technical } \\
\text { skills }\end{array}$ & 1 \\
\hline
\end{tabular}

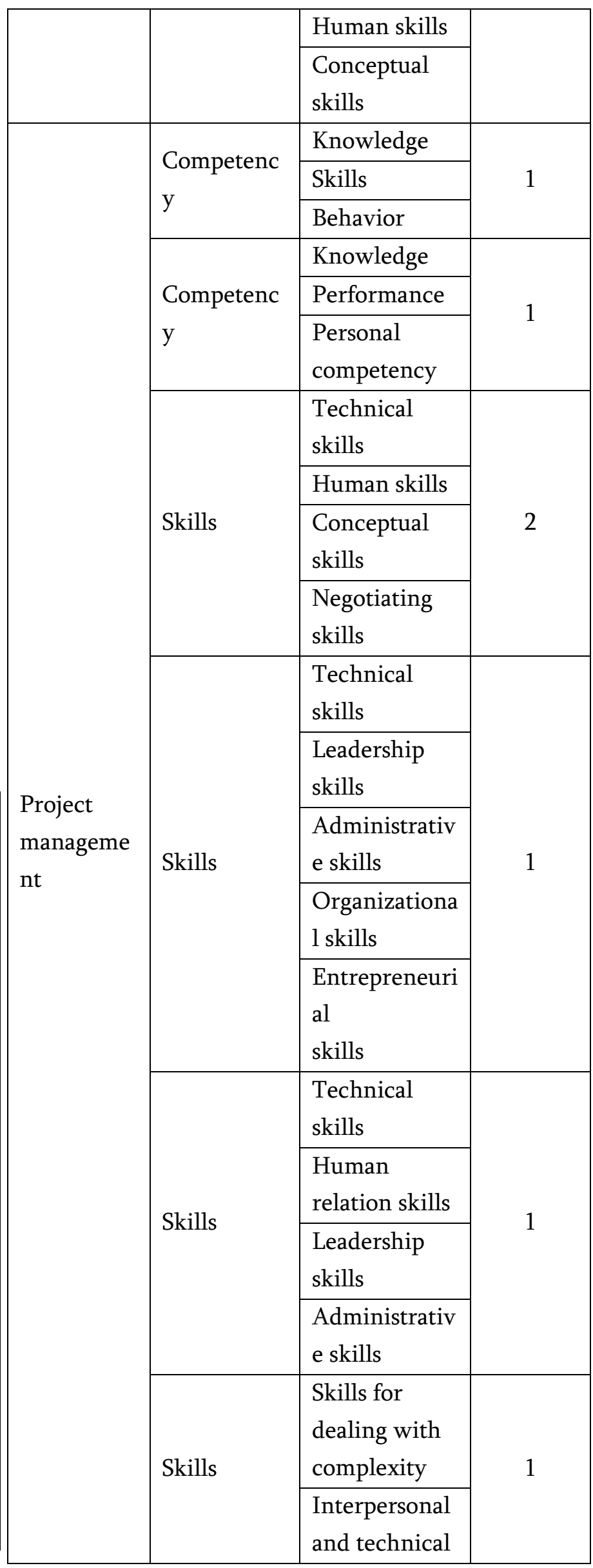




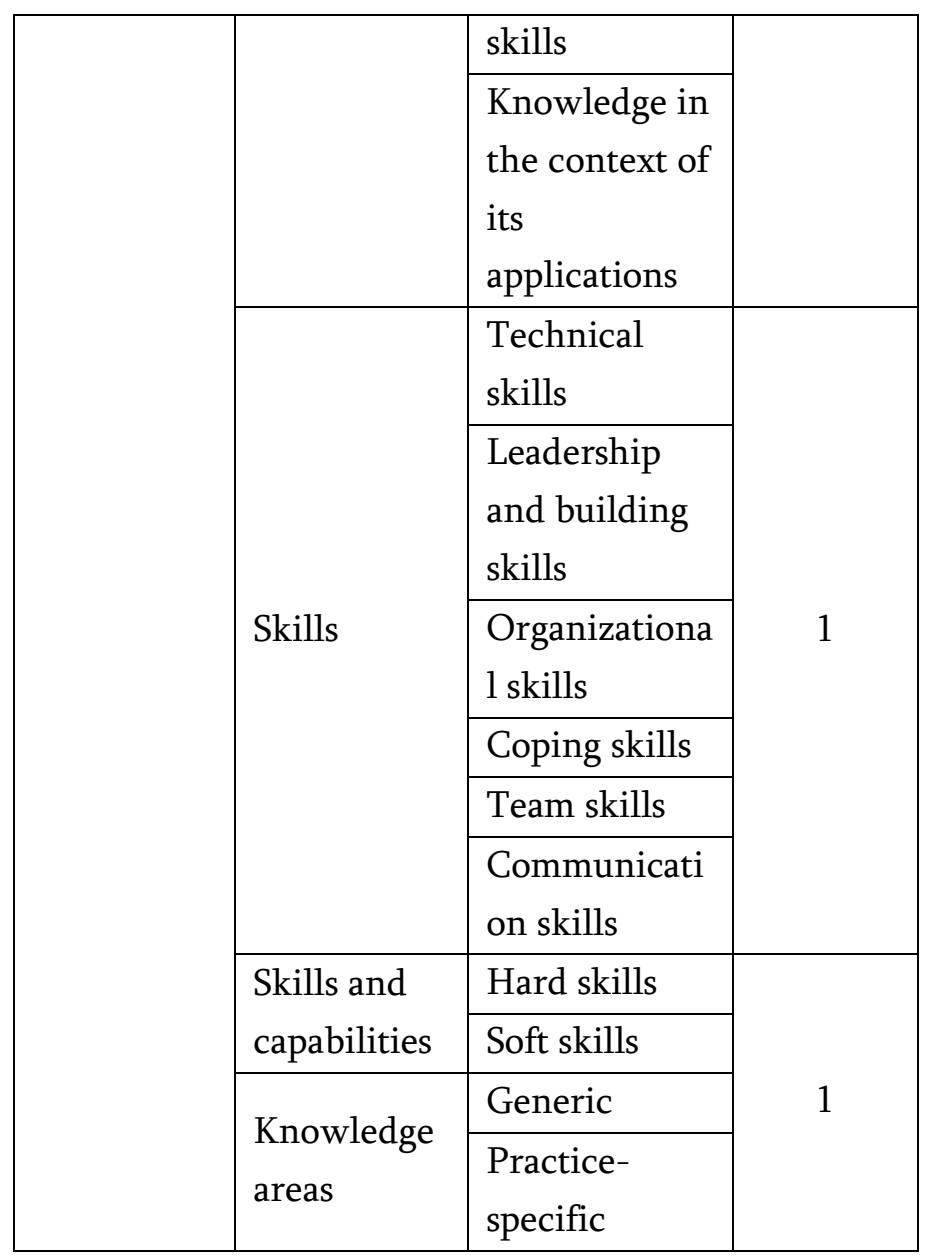

Table 8 shows how skills were categorized in category III, including the subject areas "engineering," "leadership in engineering," and "engineering management." In this category, all classifications include the component "technical skills," which was a component of all skill classifications in both subject areas "management" and "project management" in category II. In the subject areas "engineering" and "leadership in engineering," skills were divided into nontechnical and technical skills. Nontechnical skills, e.g. communication skills, teamwork, management, leadership skills, entrepreneurial skills lifelong learning, professionalism, and decision-making skills (Zaharim et al., 2010, Itani and Srour, 2016), were also considered as professional and soft skills, while technical skills were treated as hard skills. The division of skills into soft and hard skills in these two areas was the same as the classification of skills and capabilities in the subject area "project management" in category II.

Furthermore, in the area "engineering management," skills were classified similarly to a way they were classified in the area "project management" in category II. Both classifications included the following components: technical, human, and conceptual skills. The only difference related to the component "negotiation skills" in the area "project management" instead of "diagnostic skills" in the area "engineering management." Diagnostic skill is defined as showing a unique talent to get at the true causes of a situation, having reviewed and evaluated a number of systems, observations, data, and information (Nelson, 1988). Keeping in mind that in the area "management," skills were classified into the components technical, human, and conceptual skills, it might be concluded that these components are the same for management in different fields, while other components such as negotiation and diagnostic skills can be different based on the field. Moreover, both different components might be considered for CPM since CPM is relevant to both areas "project management" and "engineering management".

Table 8. Classification in category III

\begin{tabular}{|l|l|l|c|}
\hline Subject area & $\begin{array}{l}\text { Main } \\
\text { eleme } \\
\text { nt }\end{array}$ & $\begin{array}{l}\text { Compone } \\
\text { nts }\end{array}$ & $\begin{array}{c}\text { Frequen } \\
\text { cy }\end{array}$ \\
\hline Engineering & Skills & $\begin{array}{l}\text { Nontechni } \\
\text { cal or } \\
\text { profession } \\
\text { al or soft } \\
\text { skills }\end{array}$ & 2 \\
\cline { 2 - 3 } & $\begin{array}{l}\text { Technical } \\
\text { or hard } \\
\text { skills }\end{array}$ & \multirow{2}{*}{2} \\
\hline Leadership in & Skills & $\begin{array}{l}\text { Nontechni } \\
\text { cal or soft } \\
\text { Engineering }\end{array}$ & 1 \\
\hline
\end{tabular}




\begin{tabular}{|l|l|l|l|}
\hline & & $\begin{array}{l}\text { Technical } \\
\text { skills }\end{array}$ & \\
\hline \multirow{4}{*}{$\begin{array}{l}\text { Engineering manage } \\
\text { ment }\end{array}$} & \multirow{2}{*}{ Skills } & $\begin{array}{l}\text { Technical } \\
\text { skills }\end{array}$ & \\
& & $\begin{array}{l}\text { Human } \\
\text { skills }\end{array}$ & \multirow{2}{*}{1} \\
& & $\begin{array}{l}\text { Conceptua } \\
\text { 1 skills }\end{array}$ \\
& & $\begin{array}{l}\text { Diagnostic } \\
\text { skills }\end{array}$ \\
\hline
\end{tabular}

Table 9 presents how categorization was executed in category IV that includes the following subject areas: Construction, Construction professionals, Construction management, and Construction project management. In the area "construction," competency was classified into technical and behavioral competencies. Technical competencies are "firmspecific technologies and production-related skills" (Walsh and Linton, 2001) developed at the company level and implemented on its construction projects (Omar and Fayek, 2014). Behavioral competencies are a mixture of knowledge, skills, abilities, motivation, beliefs, values, and interests (Shippmann et al., 2000) that improve the construction project performance (Omar and Fayek, 2014). Comparing this classification to the classification of skills into technical and nontechnical in category II, nontechnical skills might be considered the same as behavioral competencies. In the area "construction professionals," competency was categorized into its components in five ways. In the most frequent classification, competency was divided into knowledge, skills, and personal attributes, which is the same as the classification of competency into knowledge, skills, and habits/ behavior in the areas "general" and "project management." Personal attributes represent attitudes, traits, or behaviors required to do better on a specific task e.g. cost estimating (Alroomi et al., 2010). By Comparing competency components "technical" and "behavioral" in the area "construction project" with competency components "knowledge," "skills," and "behavior" in the areas "general" and "project management," it might be concluded that knowledge and skills are two main subdivisions of technical competencies. In another classification in the area "construction professionals," competency was divided into knowledge, skill/ ability, aptitude, attitude, and qualifications. Aptitude is the natural ability to acquire relatively general or specialist types of knowledge or skills (Colman, 2007). Attitude is defined as a stable, long-lasting, learned predisposition to respond to certain things in a certain way (Statt, 1998). Qualifications can be defined as educational degrees obtained and the years of professional experience (Barison and Santos, 2011). This classification is comparable to the most frequent competency classification in the area "construction professionals" if considering all three latter components as "personal attributes." In another categorization, competency was classified into general skills such as leadership, cultural dynamics, communication skills, team skills, ethics, critical thinking, and problem-solving (Ahn et al., 2012) and pure construction skills such as estimating, scheduling, project management, cost management, and construction materials and equipment utilization (Ahn et al., 2012). It is similar to classifying competency into generic and specific in the areas of "management" and "project management." Competency was also divided into soft skills and specific technical competencies. Comparing these components with the competency components in the area of "construction project," it can be concluded that behavioral competencies are soft competencies. The last competency classification in the area "construction professionals" divides competency into the following components: general, affective, cognitive, and technical competencies. General competency consists of two items "environmental awareness" and "communication" (Ahn et al., 2012). Affective competency includes three items "leadership," "collaborative skills," and "interpersonal 
skills" (Ahn et al., 2012). Cognitive competency represents an understanding of ethical issues, problem-solving, critical thinking, adaptability, interdisciplinary thinking, and an awareness of safe working practices (Ahn et al., 2012). In another categorization, the following levels were considered for competence: level I- Recognition; level IIUnderstanding; and level III- ability. A recognition is defined as the act of knowing someone or something because of knowing or learning about them in the past (Longman, 2020c). An understanding, on the other hand, is defined as knowledge about something, based on learning or experience (Longman, 2020d). An ability is considered as someone's level of skill at doing something (Longman, 2020a). The other classification in the area "construction professionals" is related to outcomes. In the corresponding reference, outcomes were defined as what individuals were expected to know and be able to do (Anderson and Fridley, 2013). Outcomes were divided into foundational, e.g. mathematics, natural sciences, humanities, and social sciences (Anderson and Fridley, 2013), technical, e.g. materials science, mechanics, experiments, problem recognition and solving, and risk and uncertainty (Anderson and Fridley, 2013)., and professional, e.g. communication, public policy, business and public administration, globalization, leadership, teamwork, attitudes, and life-long learning (Anderson and Fridley, 2013). This classification is comparable to the skill classification in the area "engineering." The only difference related to including the category "foundational."

The competency classification in the area "construction management" was the same as a competency classification in the area "construction professionals" that included general, affective, cognitive, and technical competencies. The other classification in the area "construction management" divided knowledge areas into the following categories: technology, economy, management, and law. The knowledge area "technology" includes but not limited to building architecture and structure, civil engineering drawing and surveying, and construction materials and equipment ( $\mathrm{Hu}$ et al., 2016). The knowledge area "economy" covers micro- or macroeconomics, engineering economics, banking and insurance, and statistics ( $\mathrm{Hu}$ et al., 2016). The knowledge area "management" includes management science, construction project management, financial management, operational science, accounting, and engineering cost planning and control ( $\mathrm{Hu}$ et al., 2016). The knowledge area "law" comprises of economic law, construction regulations, engineering contract and law, and administrative regulation $(\mathrm{Hu}$ et al., 2016).

In the area "construction project management," professional competency was classified into technical and managerial skills. Managerial skills fall into three basic categories "technical," "human relations," and "conceptual skills" (BCcampus, 2020). This classification is in contrast with skill classification in the area "engineering." In the latter, professional skills were treated as nontechnical skills, while in the former, professional competency contained technical skills as one of its components. In addition, competency was divided into its categories in three ways. Two of these classifications had three similar components and one different component. The similar components were cognitive, management, and leadership competencies. Management competencies are particular skills that

a manager needs to do a job well, including leadership, people management, resource management, and organizational awareness (CambridgeDictionary, 2020). The different components were "technical /virtual competency" and "knowledge/ experience," which support our previous inference that knowledge can be considered a branch of technical competency. Knowledge/ experience competencies include but not limited to business/financial acumen, awareness of and knowledge to use state of the art technology, and any certification/training (Hanna et al., 2016). The 
third competency classification was also similar to the previous categorizations. It included cognitive and leadership competencies. It also contained knowledge and experience in the following fields: project management, operation of the involved department, and the relevant industry. Knowledge and experience in project management identify the basic set of skills, capabilities, and an undertsnading of key concepts required for an effective and successful project manager (Rezk et al., 2018). Knowledge and experience in the operation of the involved department apply specifically to the departmental standards, policies, and procedures (Rezk et al., 2018). Knowledge and experience in the relevant industry focus on an individual's technical knowledge, experience, and skills that are particularly relevant to that industry's projects (Rezk et al., 2018). The last classification in the area "construction project management" divided skills into the following components: "basic requirements," including education, communication skills, and experience (Afshari, 2017), "management skills," including planning, controlling, and organizing (Afshari, 2017), "project management skills," including resource management, time management, cost management, and quality management (Afshari, 2017), and "interpersonal skills." Based on this classification, management and project management skills should be considered two completely different skill sets.

Table 9. Classification in category IV

\begin{tabular}{|l|l|l|c|}
\hline Subject area & $\begin{array}{l}\text { Main } \\
\text { element }\end{array}$ & Components & $\begin{array}{c}\text { Frequenc } \\
\text { y }\end{array}$ \\
\hline \multirow{2}{*}{$\begin{array}{l}\text { Constructio } \\
\mathrm{n}\end{array}$} & \multirow{2}{*}{$\begin{array}{l}\text { Competenc } \\
\mathrm{y}\end{array}$} & $\begin{array}{l}\text { Technical } \\
\text { competencies }\end{array}$ & \multirow{2}{*}{1} \\
& $\begin{array}{l}\text { Behavioral } \\
\text { competencies }\end{array}$ & \\
\hline $\begin{array}{l}\text { Constructio } \\
\mathrm{n} \\
\text { professional } \\
\mathrm{s}\end{array}$ & $\mathrm{y}$ & Knowledge & \\
\cline { 3 - 3 } & $\mathrm{y}$ & $\begin{array}{l}\text { Competenc } \\
\end{array}$ & $\begin{array}{l}\text { Skills } \\
\text { attributes }\end{array}$ \\
\hline
\end{tabular}

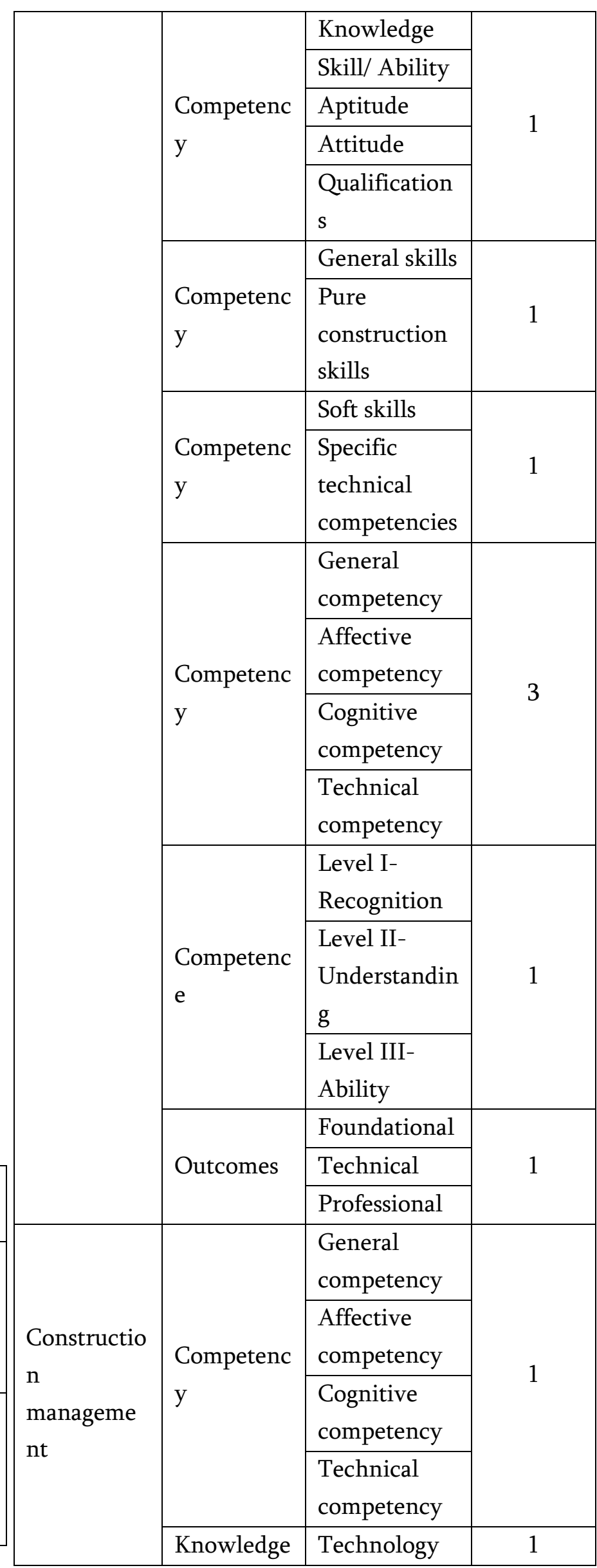




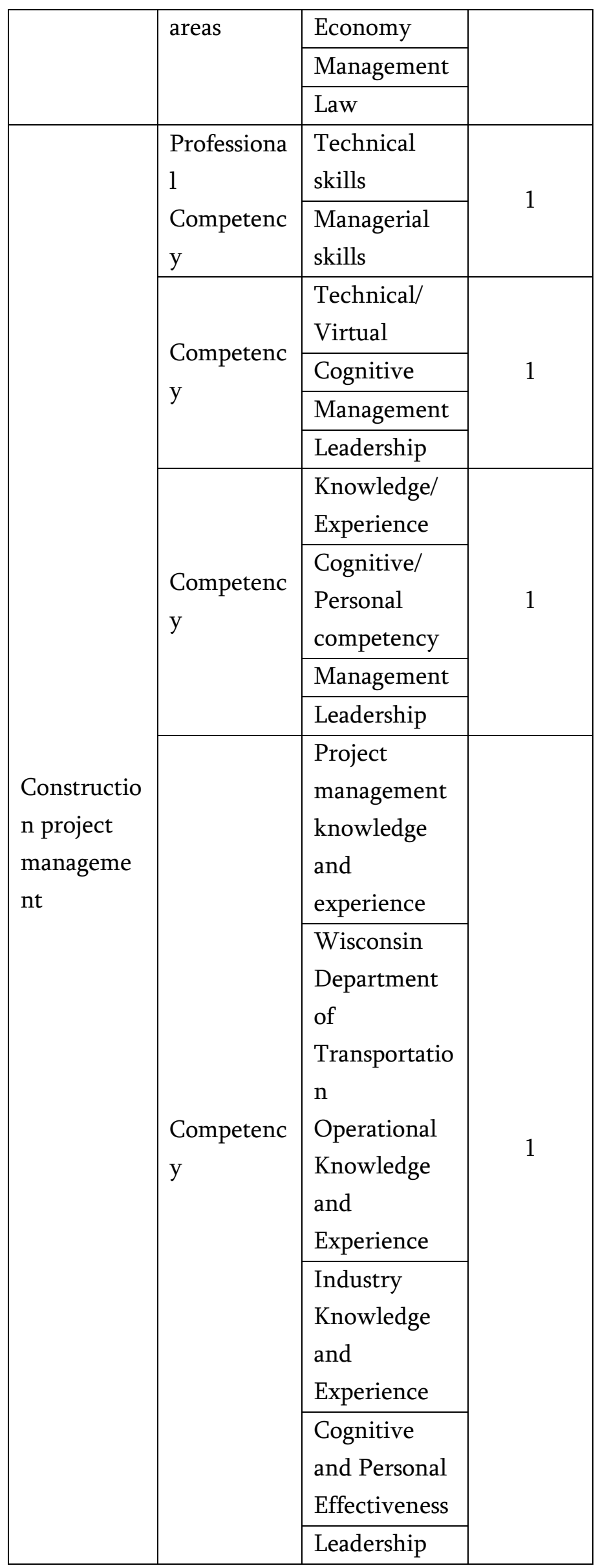

\begin{tabular}{|l|l|l|l|}
\hline & $\begin{array}{l}\text { Basic } \\
\text { requirements }\end{array}$ & \\
& \multirow{3}{*}{ Skills } & $\begin{array}{l}\text { Management } \\
\text { skills }\end{array}$ & \multirow{2}{*}{1} \\
& $\begin{array}{l}\text { Project } \\
\text { management } \\
\text { skills }\end{array}$ & \\
\hline & $\begin{array}{l}\text { Interpersonal } \\
\text { skills }\end{array}$ & \\
\hline
\end{tabular}

Furthermore, in the subject area "construction," competency components were divided into several elements, as presented in Table 10. The component "behavioral competency" was divided into the following elements: knowledge, skills, and personal attributes. This sub-classification opposes the classification of competency to knowledge, skills, and habits/ behavior. While the former classification considers knowledge and skills as elements of behavioral competencies, the latter treats knowledge, skills, and behavior as three different components of competency. Additionally, one of the competency classifications in the area of "construction professionals," subdivided knowledge and skills into soft and hard while considering personal attributes as soft (Table 10). Dividing skills into soft and hard in this subject area agrees with the classification of "skills and capabilities" into soft and hard in the area of "project management."

Moreover, comparing the classification of competency into technical and behavioral competencies in category IV with the classification of skills into technical and nontechnical skills in category II, nontechnical competencies might be considered the same as behavioral competencies. In category III, technical skills were regarded as hard skills while nontechnical skills were considered soft skills. It implies that knowledge, skills, and personal attributes as elements of behavioral competencies can be considered nontechnical competencies, thus soft 
competencies. It opposes the sub-classification of knowledge and skills into soft and hard.

Table 10. Division of competency into its elements

\begin{tabular}{|c|c|c|c|c|c|}
\hline Subject & $\begin{array}{l}\text { Main } \\
\text { elemen }\end{array}$ & \multicolumn{3}{|c|}{ Components } & Frequ \\
\hline \multirow{6}{*}{$\begin{array}{l}\text { Constru } \\
\text { ction }\end{array}$} & \multirow{6}{*}{$\begin{array}{c}\text { Compet } \\
\text { ency }\end{array}$} & \multirow{3}{*}{$\begin{array}{l}\text { Techni } \\
\text { cal }\end{array}$} & \multirow{2}{*}{$\begin{array}{l}\text { Inter } \\
\text { nal }\end{array}$} & $\begin{array}{l}\text { Practic } \\
\text { es }\end{array}$ & \multirow{6}{*}{1} \\
\hline & & & & $\begin{array}{l}\text { Operat } \\
\text { ional }\end{array}$ & \\
\hline & & & \multicolumn{2}{|c|}{ External } & \\
\hline & & \multirow{3}{*}{$\begin{array}{l}\text { Behavi } \\
\text { oral }\end{array}$} & \multicolumn{2}{|c|}{ Knowledge } & \\
\hline & & & \multicolumn{2}{|c|}{ Skills } & \\
\hline & & & \multicolumn{2}{|c|}{$\begin{array}{l}\text { Personal } \\
\text { attributes }\end{array}$} & \\
\hline \multirow{5}{*}{$\begin{array}{l}\text { Constru } \\
\text { ction } \\
\text { professi } \\
\text { onals }\end{array}$} & \multirow{5}{*}{$\begin{array}{c}\text { Compet } \\
\text { ency }\end{array}$} & \multirow{2}{*}{$\begin{array}{l}\text { Knowl } \\
\text { edge }\end{array}$} & \multicolumn{2}{|l|}{ Soft } & \multirow{5}{*}{2} \\
\hline & & & \multicolumn{2}{|l|}{ Hard } & \\
\hline & & \multirow{2}{*}{ Skills } & \multicolumn{2}{|l|}{ Soft } & \\
\hline & & & \multicolumn{2}{|l|}{ Hard } & \\
\hline & & \multicolumn{3}{|c|}{$\begin{array}{l}\text { Personal attributes } \\
\text { (Soft) }\end{array}$} & \\
\hline
\end{tabular}

\section{CONCLUSIONS AND RECOMMENDATIONS}

This paper discussed a systematic review and detailed content analysis of previous studies related to competency classification in CPM and relevant fields. The findings of the content analysis showed that the number of selected references published from 2010 through 2019 was considerably greater than in other periods. Moreover, the extracted parts of the references used for content analysis mostly belonged to no specific region. It reflects the growing demand for research on competency classification across the world in the last decade. Most of the extracted parts of selected references belonged to category IV, including the subject areas "construction," "construction " professionals," "construction management," and "construction project management." Category II, including the subject areas "leadership," "management," and "project management," was the second common category, implying that most of the classifications were related to either "construction" or "management" as two main subject areas.

This study revealed the existence of several competency classification tools and techniques in the literature that makes it increasingly challenging to select a single tool and technique for CPM competency classification. This makes it difficult to design and develop tools and methods not just for CPM training but assessment also. Future research is required to develop a framework to assist with the selection of appropriate competency classification tools and techniques. To develop such a framework, important criteria that will be considered must be identified, and a multi-criteria decision-making model should be developed.

The content analysis of selected references indicated that competency, competency synonyms, competency subdivisions, and competency branches were classified into their categories in many different ways. The evidence for this claim is that the frequency of most classifications was one, implying that there is no standard for competency classification in the field of $\mathrm{CPM}$. However, there were some similarities between different classifications, there is a lack of a consistent approach for competency classification in CPM and relevant fields. The lack of consensus in competency classification leads to considerable confusion when devising effective strategies for education, employment, and career development. It also prevents to provide an appropriate framework for the definition of competency in the context of CPM. Accordingly, providing a standard for competency classification in CPM and relevant fields is a research area of priority. Such standards will help policymakers and other key decision-makers come up with and implement the most effective strategic plans 
for well-balanced sustainable growth in education, employment, and career development to prevent potential problems or provide timely solutions (Pariafsai et al., 2021).

While this study only investigated the publications included in the ASCE Library, future work will examine other data repositories to provide a comprehensive list of competency classifications in CPM and relevant fields. More work is also required to investigate the efficiency of each CPM competency classification for different purposes (e.g. for education and training, selection and hiring, and for performance assessment).

Overall, findings of this study are sought to make recommendations for forging the path ahead by assisting the construction industry in directing its efforts toward key competency development and catering training and professional development to the real needs of the future workforce.

\section{VI.REFERENCES}

[1] AFSHARI, A. R. 2017. Methods for selection of construction project manager: Case study. Journal of Construction Engineering and Management, 143, 06017003.

[2] AFSHARI, A. R. \& NIKOLIĆ, M. 2018. Review on project manager selection criteria and methods.AHADZIE, D., PROVERBS, D. \& OLOMOLAIYE, P. 2008a. Model for predicting the performance of project managers at the construction phase of mass house building projects. Journal of Construction Engineering and Management, 134, 618-629.

[3] AHADZIE, D., PROVERBS, D. \& OLOMOLAIYE, P. 2008a. Model for predicting the performance of project managers at the construction phase of mass house building projects. Journal of Construction Engineering and Management, 134, 618-629.
[4] AHADZIE, D. K., PROVERBS, D. G. \& OLOMOLAIYE, P. 2008b. Towards developing competency-based measures for construction project managers: Should contextual behaviours be distinguished from task behaviours? International Journal of Project Management, 26, 631-645.

[5] AHMED, U. \& SAQIB, M. 2010. Optimal Solutions Of Fuzzy Relation Equations.

[6] AHN, Y. H., ANNIE, R. P. \& KWON, H. 2012. Key competencies for US construction graduates: Industry perspective. Journal of Professional Issues in Engineering Education and Practice, 138, 123-130.

[7] AL KHALIL, M. I. 2002. Selecting the appropriate project delivery method using AHP. International journal of project management, 20, 469-474.

[8] ALROOMI, A., JEONG, D., CHONG, O. \& OBERLENDER, G. Identification and assessment of cost estimating competencies. Construction Research Congress 2010: Innovation for Reshaping Construction Practice, 2010. 142-150.

[9] ALROOMI, A., JEONG, D. H. S. \& OBERLENDER, G. D. 2012. Analysis of costestimating competencies using criticality matrix and factor analysis. Journal of Construction Engineering and Management, 138, 1270-1280.

[10] ANDERSON, R. O. \& FRIDLEY, K. J. 2013. The New and Improved Civil Engineering Body of Knowledge. Raise the Bar: Strengthening the Civil Engineering Profession.

[11] ARDITI, D. \& BALCI, G. 2009. Managerial competencies of female and male construction managers. Journal of Construction Engineering and Management, 135, 1275-1278.

[12] ARENDSE, J. R. 2013. Project management competency factors in the built environment. University of Johannesburg. 
[13] ARMSTRONG, M. 2006. A handbook of human resource management practice, Kogan Page Publishers.

[14] ASSOCIATION, I. P. M. 2006. ICB-IPMA competence baseline version 3.0. International Project Management Association, Nijkerk.

[15] BALLESTEROS-SÁNCHEZ, L., ORTIZMARCOS, I., RIVERO, R. R. \& RUIZ, J. J. 2017. Project management training: an integrative approachfor strengthening the soft skills of engineering students. The International journal of engineering education, 33, 1912-1926.

[16] BARISON, M. B. \& SANTOS, E. T. 2011. The competencies of BIM specialists: a comparative analysis of the literature review and job ad descriptions. Computing in Civil Engineering (2011).

[17] BCCAMPUS. 2020. Managerial Skills [Online]. United States: BCcampus Open Education. Available:

https://opentextbc.ca/businessopenstax/chapter/ managerial-skills/ [Accessed].

[18] BIRKHEAD, M., SUTHERLAND, M. \& MAXWELL, T. 2000. Core competencies required of project managers. South African Journal of Business Management, 31, 99-105.

[19] BOTHMA, S. F. 2013. Developing project management competencies in graduate engineers in the construction industry. University of Pretoria.

[20] BOYATZIS, R. \& BOYATZIS, R. E. 2008. Competencies in the 21st century. Journal of management development.

[21] BOYATZIS, R. E. 1982. The competent manager: A model for effective performance, John Wiley \& Sons.

[22] BUNK, G. 1994. Competentieontwikkeling in de Duitse beroepsopleidingen. Development of competence in German vocational education and training. Beroepsopleiding, 1, 8-15.

[23] BUSINESSDICTIONARY. 2018. Behavior [Online]. WebFinance Inc. Available: http://www.businessdictionary.com/definition/ behavior.html [Accessed].

[24] CAMBRIDGEDICTIONARY. 2020.

Management Competencies [Online]. United Kingdom: Cambridge University Press. Available:

https:/dictionary.cambridge.org/us/dictionary/e nglish/management-competencies [Accessed].

[25] CHAN, A. P., CHAN, D. W. \& YEUNG, J. F. 2009. Overview of the application of "fuzzy techniques" in construction management research. Journal of construction engineering and management, 135, 1241-1252.

[26] CHENG, M. I., DAINTY, A. R. \& MOORE, D. R. 2005. What makes a good project manager? Human resource management journal, 15, 2537.

[27] COLMAN, A. M. 2007. A Dictionary of Psychology. 2001. Oxford University Press, Oxford. COLORADO STATE UNIVERSITY. CON, 562, 121-146.

[28] CÓRDOBA, J.-R. \& PIKI, A. 2012. Facilitating project management education through groups as systems. International Journal of Project Management, 30, 83-93.

[29] CRAWFORD, L. 2005. Senior management perceptions of project management competence. International journal of project management, 23, 7-16.

[30] DAINTY, A. R., CHENG, M. I. \& MOORE, D. R. 2004. A competency-based performance model for construction project managers. Construction Management and Economics, 22, 877-886.

[31] EDUM-FOTWE, F. T. \& MCCAFFER, R. 2000. Developing project management competency: perspectives from the construction industry. International Journal of Project Management, 18, 111-124.

[32] ENGESTRÖM, Y. 1994. Training for change: New approach to instruction and learning in 
working life, International Labour Office Geneva.

[33] FAROOQUI, R. U., AHMED, S. \& SAQIB, M. Desirable attributes and skills for graduating construction management students. 46th Annual Conference hosted by Wentworth Institute of Technology Boston, Boston, USA, 2010.

[34] FAROOQUI, R. U. \& AHMED, S. M. Key Skills for Graduating Construction Management Students-A Comparative Study of Industry and Academic Perspectives. Construction Research Congress 2009: Building a Sustainable Future, 2009. 1439-1448.

[35] FLETCHER, S. 1997. Analysing competence: tools and techniques for analysing jobs, roles and functions, Kogan Page Publishers.

[36] FREI, F., DUELL, W. \& BAITSCH, C. 1984. Arbeit und Kompetenzentwicklung: theoretische Konzepte zur Psychologie arbeitsimmanenter Qualifizierung, Huber.

[37] GAPPS 2007. A framework for performance based competency standards for global level 1 and 2 project managers.

[38] GARETH, R. 1997. Recruitment And Selection A Competency Approach. London: Chartered Institute of Personnel and Development (CIPD).

[39] GOULD, M. \& FREEMAN, R. 2004. The art of project management: a competency model for project managers. White Paper] BUCEC, Boston.

[40] HANNA, A. S., IBRAHIM, M. W., LOTFALLAH, W., ISKANDAR, K. A. \& RUSSELL, J. S. 2016. Modeling project manager competency: an integrated mathematical approach. Journal of Construction Engineering and Management, 142, 04016029.

[41] HU, X., XIA, B., YE, K. \& SKITMORE, M. 2016. Underlying knowledge of construction management consultants in China. Journal of
Professional Issues in Engineering Education and Practice, 142, 04015015.

[42] ITANI, M. \& SROUR, I. 2016. Engineering students' perceptions of soft skills, industry expectations, and career aspirations. Journal of professional issues in engineering education and practice, 142, 04015005.

[43] KAKLAUSKAS, A., AMARATUNGA, D. \& LILL, I. 2010. The life cycle process model for efficient construction manager: conceptual modelling at the level of personality and at micro, meso and macro levels.

[44] KATZ, R. L. 2009. Skills of an effective administrator, Harvard Business Review Press.

[45] KERZNER, H. 2017. Project management: a systems approach to planning, scheduling, and controlling, John Wiley \& Sons.

[46] KIM, S.-Y. \& HUYNH, T.-A. 2008. Improving project management performance of large contractors using benchmarking approach. International Journal of Project Management, 26, 758-769.

[47] KRIPPENDORFF, K. 2018. Content analysis: An introduction to its methodology, Sage publications.

[48] KWOK, C.-W. 2004. Competencies of Project Managers in Hong Kong. Bachelor of Science in Surveying, The University of Hong Kong.

[49] LIMSILA, K. \& OGUNLANA, S. O. 2008. Linking personal competencies with transformational leadership style evidence from the construction industry in Thailand. Journal of Construction in Developing Countries, 13, 27-50.

[50] LINDBERGH, L. B. 2009. The relationship between project manager perceived capability, organizational culture, and project outcomes. Capella University.

[51] LONGMAN. 2020a. Ability [Online]. United Kingdom: Pearson. Available: https://www.ldoceonline.com/dictionary/ability [Accessed]. 
[52] LONGMAN. 2020b. Habit [Online]. United Kingdom: Pearson. Available: https://www.ldoceonline.com/dictionary/habit [Accessed June 16 2020].

[53] LONGMAN. 2020c. Recognition [Online]. United Kingdom: Pearson. Available: https://www.ldoceonline.com/dictionary/recog nition [Accessed].

[54] LONGMAN. 2020d. Understanding [Online]. United Kingdom: Pearson. Available: https://www.ldoceonline.com/dictionary/under standing [Accessed].

[55] LOVE, P., HAYNES, N., SOHAL, A. S., CHAN, A. \& TAM, C. 2002. Key construction management skills for future success. Monash University. Faculty of Business and Economics. Working paper.

[56] MCCLELLAND, D. C. 1973. Testing for competence rather than for" intelligence.". American psychologist, 28, 1.

[57] MEADE, L. M. \& PRESLEY, A. 2002. R\&D project selection using the analytic network process. IEEE transactions on engineering management, 49, 59-66.

[58] NELSON, C. E. 1988. Engineering Management: Recognizing Potential Engineering Managers. Journal of Management in Engineering, 4, 83-92.

[59] OGUNSANMI, O. E. 2016. Determining the essential skill requirements for construction managers 'practice in Nigeria. International Journal of Construction Supply Chain Management, 6, 48-63.

[60] OKOYE, P. U., NGWU, C. \& UGOCHUKWU, S. C. 2015. Methodical Approach of Determining Labour Constants Models for Building Construction Processes in Nigeria. International Journal of Engineering Research and General Sciences, 3.

[61] OMAR, M. N. \& FAYEK, A. R. A framework for identifying and measuring competencies and performance indicators for construction projects. Construction Research Congress 2014: Construction in a Global Network, 2014. 20432052.

[62] OMRAN, A. \& AKRAM, S. 2017. Identifying the competence components of the construction project managers in the Palestinian construction industry. Engineering Project Organization Journal, 1, 135-160.

[63] PARIAFSAI, F. 2013. Management and Construction Equipment Vol. 1. Tehran, Iran: Adabestan.

[64] PARIAFSAI, F. 2016a. Effectiveness of a virtual project-based simulation game in construction education. International Journal of Scientific Research in Science, Engineering and Technology (IJSRSET), 2, 377-393.

[65] PARIAFSAI, F. Effectiveness of Virtual ProjectBased Simulation Games at Different levels of Construction Education. 5th International conference on Science \& Engineering, Paris, France, 2016b.

[66] PARIAFSAI, F. Project-Based Simulation Game: an Effective Learning Tool for Students with Limited Prior Education in Construction. 3rd International Conference on New Research Achievements in Civil, Architecture \& Urban Management, Tehran, Iran, September 16th, 2016c.

[67] PARIAFSAI, F. Project-Based Simulation Games as Effective Tools in Education of Inexperienced Construction Students. 3rd International Conference on Recent Innovations in Civil Engineering, Architecture and Urban Planning, Tehran, Iran, September 8th, 2016d.

[68] PARIAFSAI, F. 2016e. A review of design considerations in glass buildings. Frontiers of Architectural Research, 5, 171-193.

[69] PARIAFSAI, F. 2016f. Strengths \& Weaknesses of a Project-Based Simulation Game as an Educational Tool. 
[70] PARIAFSAI, F. 2016g. Students' View on Potential of a Project-Based Simulation Game for Construction Education. International Journal of Scientific Research in Science, Engineering and Technology, 2, 514-523.

[71] PARIAFSAI, F. Virtual Project-Based Simulation Games: Effectiveness in Construction Education of Different Genders. 4th International Conference on Modern Research in Civil Engineering, Architectural \& Urban Development, Barcelona, Spain, October 14th, 2016h.

[72] PARIAFSAI, F. 2020. Replication Data for: Review of Classification of Key Competencies for CPM (ASCE 1988-2019) October 2020. V2 ed.: Texas Data Repository.

[73] PARIAFSAI, F. \& BEHZADAN, A. H. 2021. Core Competencies for Construction Project Management: Literature Review and Content Analysis. Journal of Civil Engineering Education, 147, 04021010.

[74] PARIAFSAI, S., DALENBERG, D., ELLISON, C., JOHNSON, L. \& PARIAFSAI, F. 2021. Association of Freshman Retention Rates with Instructional Expenditure and Residential Status : A Case Study for Large Public Colleges. International Journal of Scientific Research in Science, Engineering and Technology, 8, 11-21.

[75] PARRY, S. 1997. JustWhatIsacompetency. AndWhyShould Youcare.

[76] PMI. Project Manager Competency Development: Framework. 2007. Project Management Institute.

[77] PRIETO, B. 2013. Establishing and building leadership skills. Leadership and Management in Engineering, 13, 209-211.

[78] REZK, S., WHITED, G. \& HANNA, A. Quantitative Assessment of Project Manager Competencies for Wisconsin Department of Transportation. Construction Research Congress 2018, 2018. 702-711.
[79] SEWCHURRAN, K., NAMWILA, M. \& RAKUBUTU, T. 2010. Exploring the development of Project Management competency amongst IS Professionals. Available from: web. up. ac. za/ecis/SACLA2010PR/SACLA2010/.../SACLA0 01. pdf ....

[80] SHIPPMANN, J. S., ASH, R. A., BATJTSTA, M., CARR, L., EYDE, L. D., HESKETH, B., KEHOE, J., PEARLMAN, K., PRIEN, E. P. \& SANCHEZ, J. I. 2000. The practice of competency modeling. Personnel psychology, 53, 703-740.

[81] SPENCER, L. M. \& SPENCER, P. S. M. 2008. Competence at Work models for superior performance, John Wiley \& Sons.

[82] STATT, D. A. 1998. The concise dictionary of psychology, Taylor \& Francis US.

[83] STREUMER, J. N. \& BJORKQUIST, D. C. 1998. Moving beyond traditional vocational education and training: emerging issues. Key qualifications in work and education. Springer.

[84] TOOR, S. U. R. \& OGUNLANA, S. O. 2008. Problems causing delays in major construction projects in Thailand. Construction management and economics, 26, 395-408.

[85] TURNER, D. \& CRAWFORD, M. H. 1992. Managing current and future competitive performance: The role of competence, Centre for Corporate Change, Australian Graduate School of Management, The ....

[86] VAN KLINK, M. R. D. \& BOON, J. 2003. Competencies: The triumph of a fuzzy concept. International Journal of Human Resources Development and Management, 3, 125-137.

[87] VAZIRANI, N. 2010. Review paper competencies and competency model-A brief overview of its development and application. SIES Journal of management, 7, 121-131.

[88] WALSH, S. T. \& LINTON, J. D. 2001. The competence pyramid: A framework for identifying and analyzing firm and industry 
competence. Technology analysis \& strategic management, 13, 165-177.

[89] YOUNG, B. A. 1989. Management skills and knowledge: a case example from the construction industry. Leadership \& Organization Development Journal.

[90] ZAHARIM, A., YUSOFF, Y. M., MOHAMED, A., OMAR, M. Z., MUHAMAD, N. \& MUSTAPHA, R. Practical framework of employability skills for engineering graduate in Malaysia. IEEE EDUCON 2010 Conference, 2010. IEEE, 921-927.

[91] ZARTMAN, I. W. 1976. The 50\% solution: How to bargain successfully with hijackers, strikers, bosses, oil magnates, Arabs, Russians, and other worthy opponents in this modern world, Yale University Press.

\section{REFERENCES}

[1]. Prof. R.M.Sahu, Akshay Godase, Pramod CONTROL ENGINEERING, Vol. 4.

[2]. Kanchan Mahajan, Proff.J.S.Chitode, "Waste Bin Monitoring

\section{Cite this article as :}

Fatemeh Pariafsai, Sadjad Pariafsai, "Classification of Key Competencies for Construction Project Management: Literature Review and Content Analysis", International Journal of Scientific Research in Science, Engineering and Technology (IJSRSET), Online ISSN : 2394-4099, Print ISSN : 2395-1990, Volume 8 Issue 3, pp. 211-234, May-June 2021. Available at doi : https://doi.org/10.32628/IJSRSET218334 Journal URL : https://ijsrset.com/IJSRSET218334 